\title{
Spatiotemporal dynamics of calcium and calmodulin at the spine Georgios Kalantzis ${ }^{1}$, Naveed Aslam ${ }^{1}$ and Harel Z Shouval ${ }^{* 1,2,3}$
}

\author{
Address: ${ }^{1}$ Department of Neurobiology and Anatomy, The University of Texas Medical School, Houston, Texas, USA, ${ }^{2}$ Department of Biomedical \\ Engineering, The University of Texas, Austin, Texas, USA and 'Institute for Brain and Neural Systems, Brown University, Providence, Rhode Island, \\ USA \\ Email: Harel Z Shouval* - harel.shouval@uth.tmc.edu \\ * Corresponding author
}

from Sixteenth Annual Computational Neuroscience Meeting: CNS*2007

Toronto, Canada. 7-12 July 2007

Published: 6 July 2007

BMC Neuroscience 2007, 8(Suppl 2):P92 doi:10.1 I86/147|-2202-8-S2-P92

(C) 2007 Kalantzis et al; licensee BioMed Central Ltd.

Calcium levels in spines play a significant role in determining the sign and magnitude of synaptic plasticity. Recent experiments using calcium sensitive dyes have allowed measurements of calcium transients in whole spines, however experimental resolution does not allow imaging of the spatial distribution of calcium within the spine $[1,2,5]$. Calcium can activate Calcineurin or bind to $\mathrm{CaM}$ and consequently activate CaMKII which is key mediator of synaptic plasticity. A main source of calcium influx into the spine is from the NMDA receptors. There are four different subtypes of obligatory NR2 subunits of $\mathrm{NMDA}$ receptors, $\mathrm{NR} 2 \mathrm{~A} / \mathrm{B} / \mathrm{C} / \mathrm{D}$. In the mature cortex the majority of the synaptic NMDA receptors are constituted by NR1/NR2A and in the immature cortex by NR1/NR2B. Experiments have shown that the subunit composition of NMDA receptors has an influence on the sign of synaptic plasticity, but different experiments resulted in different and possibly conflicting results $[3,4]$. NR2B has slower kinetics and higher affinity for Glutamate than that of NR2A. In addition NR2B receptors have a binding site for CaMKII.

For the study of the spatiotemporal dynamics of Calcium and Calmodulin we implemented a compartmental model of the spine head including the neck. We also simulated an intrinsic calcium buffer and calcium pumps on the surface of the spine. Calcium pumps and as well as NMDA receptors were simulated by Markov models [7]. Using this model we observe the spatiotemporal distribution of calcium and calcium-calmodulin transients. We find that the calcium pumps as well as the geometry of the neck affects the spatiotemporal dynamics of calcium and consequently of calmodulin, and that different NMDA receptor subunits differentially affect this distribution.

Finally, in the past it has been shown that stochasticity of calcium transients can affect plasticity rules [6]. We hypothesize that the main source of stochasticity of calcium transients at the spine arises from the stochasticity of NMDA receptor opening and presynaptic release. We investigate the validity of our hypothesis using a stochastic model for the spine. In that way we compare the calcium and calmodulin dynamics of the stochastic model with those of deterministic and hybrid models.

\section{References}

I. Majewska A, Brown E, Ross J, Yuste RR: Mechanisms of calcium decay kinetics in hippocampal spines: role of spine calcium pumps and calcium diffusion through the spine neck in biochemical compartmentalization. I Neurosci 2000, 20(5): $1722-1734$

2. Volfovsky N, Parnas H, Segal M, Korkotian E: Geometry of dendritic spines affects calcium dynamics in hippocampal neurons: Theory and experiments. J Neurophysiol 1999, 82:450-462.

3. Liu L, Wong TP, Pozza MF, Lingenhoehl K, Wang Y, Sheng M, Auberson YP, Wang YT: Role of NMDA receptor subtypes in governing the direction of hippocampal synaptic plasticity. Science 2004, 304(5673): 102I-1024.

4. Barria A, Malinow R: NMDA receptor subunit composition controls synaptic plasticity by regulating binding to CaMKII. Neuron 2005, 48:289-30I.

5. Sabatini BL, Svoboda K: The life sycle of calcium ions in dendritic spines. Neuron 2002, 33:439-452.

6. Shouval HZ, Kalantzis G: Stochastic properties of synaptic transmission affect the shape of spike time dependent plasticity curves. J Neurophysiol 2005, 93:1069-1073. 
7. Erreger K, Dravid SM, Banke TG, Wyllie DJ, Traynelis SF: Subunitspecific gating controls rat NRI/NR2A and NRI/NR2B NMDA channel kinetics and synaptic signalling profiles. J Physiol 2005, 563:345-358.

Publish with Biomed Central and every scientist can read your work free of charge

"BioMed Central will be the most significant development for disseminating the results of biomedical research in our lifetime. " Sir Paul Nurse, Cancer Research UK

Your research papers will be:

- available free of charge to the entire biomedical community

- peer reviewed and published immediately upon acceptance

- cited in PubMed and archived on PubMed Central

- yours - you keep the copyright 